\begin{tabular}{|l|l|l||}
\hline \multicolumn{2}{|c|}{ PublisherInfo } \\
\hline \hline PublisherName & $:$ & BioMed Central \\
\hline \hline PublisherLocation & $:$ & London \\
\hline \hline PublisherImprintName & $:$ & BioMed Central \\
\hline \hline
\end{tabular}

\title{
Articles selected by Faculty of 1000 Biology: bacterial chromosome segregation; a protein structure initiative; subcellular plant protein localization; transcriptional reprogramming of atrophic muscle; sex-determined recombination levels.
}

\begin{tabular}{|l|l|l||}
\hline \multicolumn{2}{|c||}{ ArticleInfo } \\
\hline \hline ArticleID & $:$ & 3523 \\
\hline \hline ArticleDOI & $:$ & $10.1186 /$ gb-2005-6-11-357 \\
\hline \hline ArticleCitationID & $:$ & 357 \\
\hline \hline ArticleSequenceNumber & $:$ & 19 \\
\hline \hline ArticleCategory & $:$ & Paper report \\
\hline \hline ArticleFirstPage & $:$ & 1 \\
\hline \hline ArticleLastPage & $:$ & 3 \\
\hline \hline ArticleHistory & $:$ & RegistrationDate : 2005-11-1 \\
\hline
\end{tabular}




\begin{tabular}{|c|c|}
\hline & OnlineDate $\quad:$ 2005-11-1 \\
\hline ArticleCopyright & BioMed Central Ltd2005 \\
\hline ArticleGrants & \\
\hline ArticleContext & 13059661111 \\
\hline
\end{tabular}

The Author(s)

\section{Summary}

A selection of evaluations from Faculty of $\mathbf{1 0 0 0}$ Biology covering bacterial chromosome segregation; a protein structure initiative; subcellular plant protein localization; transcriptional reprogramming of atrophic muscle; sex-determined recombination levels.

\section{Bacterial chromosome segregation}

Dancing around the divisome: asymmetric chromosome segregation in Escherichia coli . Wang X, Possoz C, Sherratt DJ. Genes Dev 2005, 19:2367-2377.

For the Faculty of 1000 Biology evaluation of this article please see: http://genomebiology.com/ reports/F1000/gb-2005-6-11-357.asp\#Wang

\section{Protein structure initiative}

New York-Structural GenomiX Research Consortium (NYSGXRC): a large scale center for the Protein Structure Initiative. Bonanno JB, Almo SC, Bresnick A, Chance MR, Fiser A, Swaminathan S, Jiang J, Studier FW, Shapiro L, Lima CD, et al. J Struct Funct Genomics 2005, 6:225-232.

For the Faculty of 1000 Biology evaluation of this article please see: http://genomebiology.com/ reports/F1000/gb-2005-6-11-357.asp\#Bonanno

\section{Subcellular plant protein localization}


Combining experimental and predicted datasets for determination of the subcellular location of proteins in Arabidopsis . Heazlewood JL, Tonti-Filippini J, Verboom RE, Millar AH. Plant Physiol 2005, 139:598-609.

For the Faculty of 1000 Biology evaluation of this article please see: http://genomebiology.com/ reports/F1000/gb-2005-6-11-357.asp\#Heazlewood

\section{Transcriptional reprogramming of atrophic muscle}

Transcriptional reprogramming during reloading of atrophied rat soleus muscle. Flück $\mathrm{M}$, Schmutz S, Wittwer M, Hoppeler H, Desplanches D. Am J Physiol Regul Integr Comp Physiol 2005, 289:R4-R14.

For the Faculty of 1000 Biology evaluation of this article please see: http://genomebiology.com/ reports/F1000/gb-2005-6-11-357.asp\#Fluck

\section{Sex-determined recombination levels}

Sex, not genotype, determines recombination levels in mice. Lynn A, Schrump S, Cherry J, Hassold T, Hunt P. Am J Hum Genet 2005, 77:670-675.

For the Faculty of 1000 Biology evaluation of this article please see: http://genomebiology.com/ reports/F1000/gb-2005-6-11-357.asp\#Lynn

This PDF file was created after publication. 